\title{
Using academic technology: Transfer methods and licensing incidence in the commercialization of American diagnostic imaging equipment research, 1954-1988*
}

\author{
Will MITCHELL \\ School of Business Administration, University of Michigan, Ann Arbor, MI 48109-1234, USA
}

Final version received September 1990

\begin{abstract}
This paper reports a study of licensing incidence and technology transfer methods used between the mid 1950s and late $1980 \mathrm{~s}$ in alınost 200 cases of commercialization of American academic medical diagnostic imaging equipment. I show that methods used to transfer goods and ideas from academic researchers to corporate manufacturers are changing. Although contact between individual researchers and commercializing firms remains critically important, organization-level contact between the research institution and corporation is becoming more common. The likelihood of licensing has increased since the passage of PL $96-517$ in 1980, but only in academic institutions that have established formal in-house patent and license offices. The paper also discusses several general issues relating to the role of academic patent and license offices in effective technology transfer.
\end{abstract}

\section{Introduction}

Academic and quasi-academic institutions have long been important initial sources of commercial goods [16-20]. Many medical devices, pharmaceutical compounds, industrial instruments, computer programs, and pollution control devices, for instance, have first emerged as well-developed designs or, more frequently, as partially formulated research ideas, in university and medical school laboratories in North America, Europe and Japan.

\footnotetext{
* Parts of this research were supported by the generous assistance of the Licensing Executives Society and the Social Sciences and Humanities Research Council of Canada. I am particularly grateful for the assistance of Mr. Edmund G. Astolfi of the Licensing Executive Society.
}

Research Policy 20 (1991) 203-216

North-Holland
Cancer-suppressing biotechnological drugs, industrial spectroscopic devices, artificial hearts, and Vitamin $D$ are just a few such existing goods $[1,28]$. AIDS vaccines and new sources may emerge in the future, drawing on current academic research. But although academic research remains an important source of commercial goods, the methods by which academic advances are transferred to commercial producers are changing.

Traditionally, most ideas and designs have been transferred to corporate producers informally, via hands off methods such as academic publications or through individual contact methods such as hiring students or consulting with researchers $[3,7,8,15,16,27]$. As recently as the late $1970 \mathrm{~s}$, as Niels Reimers noted, "many universities [had] no ... mechanism for licensing of research results" [19]. Even universities with licensing mechanisms often did not operate an on-campus patent and licensing office, choosing instead to contract with external patent and license agents, which give high ratings only to the most promising ideas [4] and so might file for only a few patents each year at any one academic institution. In the past decade, however, universities throughout the world have attemped to capture part of the revenue generated by academic research $[3,5,28]$.

In the United States, several factors have led many universities and medical schools to change their transfer practices. Increasing research costs, plateauing public financial support in many research fields, increasing political and faculty demands for improved technology transfer, and 
changing laws governing the right to hold patents all came into play during the 1980s [9]. Following the passage of PL 96-517 (the U.S. Patent and Trademark Amendments Act of 1980, Chapter 38, Patent Rights in Inventions Made With Federal Assistance, enacted December 12, 1980) which granted universities the right to license patents generated through government-sponsored research [3], many universitics established or expanded formal patent, copyright, and licensing offices. One reason to establish the formal offices is to generate income for the institutions and the individual researchers $[9,11]$. At the same time, academic institutions hope to increase the likelihood that technology will be transferred to commercial practice [2], rather than gather rust on a laboratory shelf or molder in a filing cabinet drawer. Many university and commercial figures expected the 1980 law to improve the chances for better university-industry research relationships [8]. But how effective the offices will be is still an open question. Is commercialized academic research now more likely to be licensed than before? Is it more likely to be transferred than before?

In this paper, I report results from a study of licensing incidence and technology transfer methods used since the mid 1950s in almost 200 cases of commercialization of academic medical diagnostic imaging equipment. I show that transfer methods are changing and that the likehood of licensing has increased, especially when academic institutions have established formal in-house patent and license offices. I also discuss several general issues relating to the role of academic patent and license offices in effective technology transfer.

Academic research has played a particularly important role in generating commercial medical advances $[6,23]$. Within the medical sector, diagnostic imaging instrumentation has been a particularly important application of academic design research $[21,22,24]$. Studying changes in medical diagnostic imaging equipment technology transfer methods and licensing incidence, therefore, clarifies the changes that are occurring throughout the institutions of academic commercialization.

It is still too early to judge the success of the new offices. Many institutions are in preliminary stages of development: building patent portfolios, acquiring the skills needed to identify licensors and negotiate successful agreements, expanding from central campus offices to multi-campus operations, and experimenting with new technology transfer methods, such as equity participation. It is possible, however, to document methods used to transfer academic technology to commercial development and to identify changes in licensing incidence during the 1980s. Here, I report the results of such a study.

The paper proceeds in 6 parts. In part 2, I discuss diagnostic imaging equipment and identify the sources used to collect information about transfer of imaging device knowledge from academic institutions to corporate manufacturers. In parts 3 and 4, I identify transfer methods used and changes in the relative incidence of the methods since the 1950s and then discuss changes in licensing incidence. In part 5, I extend the discussion to the broader of transfer incidence, revenue generation, and effective transfer. Finally, in part 6 , I conclude the paper with a brief summary.

\section{Diagnostic imaging equipment and study data}

Diagnostic imaging equipment helps physicians and other health care workers obtain information about internal organs and physiological activity. Commercial $x$-ray imaging devices were introduced within a year of Roentgen's discovery of $\mathrm{X}$ rays in 1896, while electrodiagnostic devices, such as electrocardiographs and electroencephalographs, were introduced early in this century. Both classes of instrument quickly became key parts of medical practice. The introduction of nuclear medical and ultrasonic imaging equipment in the 1950 s and $1960 \mathrm{~s}$, followed by computed tomography (CT) scanners in the 1970s, and then magnetic resonance imaging (NMR or MRI) and digital radiographic equipment during the $1980 \mathrm{~s}$, expanded the field of diagnostic imaging and further assisted medical care [13]. More recently, picture archiving and communications systems (PACS) devices have been introduced to store and transmit images produced by the imaging generating equipment.

Many commercial imaging devices introduced since the early 1950 s began life as research prototypes in university and medical school laboratories. Some devices were designed by clinical practitioners who, as users of medical equipment, needed products that were not available commer- 
cially. Other devices were designed by university and medical school-based researchers aiming to improve medical practice, advance their careers, satisfy their curiosity, and/or gain financial rewards. ${ }^{1}$ Through formal and informal methods, the knowledge required to replicate and improve the devices was then transferred to commercial manufacturers, which introduced commercial prototypes. Some prototypes then went on to become clinically useful commercial instruments [14]. As part of an ongoing research project, I have identified most firms that have manufactured diagnostic imaging equipment to be sold to the U.S. market since 1950 and have documented the sources from which the manufacturers obtained much of the key knowledge incorporated in the commercial designs. In this paper, I discuss cases in which the know-ho was acquired from academic institutions.

The products in this study include conventional $\mathrm{x}$-ray, electrodiagnostic, nuclear medical, ultrasonic, computed tomographic, magnetic resonance, digital radiographic and PACS devices that were introduced to United States markets between 1954 and 1988. To keep the study within reasonable bounds, I omitted substances, such as radiopharmceuticals and contrast media, that are used with diagnostic imaging instruments but are not themselves devices. Only products that achieved introduction as commercial prototypes were included, with commercial introduction being judged as placement at a site other than the manufacturer's plant. Thus, products that did not proceed beyond the stage of being research prototypes within a manufacturer's plant were excluded from the study, but commercial prototypes that failed in clinical trials or were otherwise unsuccessful are included.

1 The frequency of academic sites as the locus of research prototype development is largerly consistent with von Hippel's $[25,26]$ findings that users are key sources of scientific equipment innovation and of innovation in general. However, although clinical practitioners' role as users of imaging devices is a key factor in the innovation, other factors also apply. Rather than being users of the new devices, some of the innovators were engineers and academics whose motivation related to entrepreneurial of career advancement goals as well as to applying new products to their own use. While the proximity to users was an important factor in such cases, so was the proximity to key basic knowledge and the availability of public funding for the research.
The data for this study were drawn from an extensive archival search of the business, government, and academic press, followed by interviews with industry and academic personnel. I first identified corporate participants in the industry by the archival search, attempting also to identify cases in which a firm had acquired key know-how form an academic source. Key know-how was defined as a design idea that was identified as integral to the product. In some cases, a design idea was obtained by a company after being fully developed elsewhere. More often, though, it was necessary for the company to modify the design before the product was ready for commercial introduction. I then contacted more than 100 individuals who had been associated with the companies to confirm the participation and know-how acquisition and to determine what methods of acquiring know-how had been used. Individuals were identified based on references in the academic and business literature and on recommendations from earlier contacts.

Over 300 cases of diagnostic imaging know-how acquired from international academic institutions were identified, with the cases that related to American universities and medical schools being retained. I omitted quasi-academic research institutes, such as the Battelle Institute and Stanford Research Institute, and national labs, such as the Oakridge National Laboratory and Argonne National Laboratory. These are important and fascinating sources of technology, but require separate study.

When the publications or interviews identified an American university or medical school as the source of some aspect of a firm's product, I conlacted the university in order to obtain information about patenting and licensing of the knowhow. When possible, I spoke with a person responsible for managing the institution's medical equipment licensing activities. Those people usually were employed by a formal patent and license office or a university attorney's office or were faculty members who ran a technology transfer office on a part-time basis. I also spoke with personnel at two organizations that have acted as external patent and license agents for academic institutions. In addition to obtaining general information about the institution's patent and license practices, I asked several questions directly related to the results reported in this article: if the imag- 
Table 1

Number of transfers per imaging subfield by decade

\begin{tabular}{lccccc}
\hline & $1950 \mathrm{~s}$ & $1960 \mathrm{~s}$ & $1970 \mathrm{~s}$ & $1980 \mathrm{~s}$ & Total \\
\hline Nuclear medical & 6 & 11 & 26 & 27 & 70 \\
Ultrasound & 6 & 7 & 18 & 18 & 49 \\
Computed tomography & & & 4 & 17 & 19 \\
Magnetic resonance & 1 & - & - & 19 & 21 \\
Digital radiography & 13 & 18 & 59 & 101 & 11 \\
Other a & 13 & & & 191 \\
\end{tabular}

${ }^{a}$ Includes conventional $\mathrm{x}$-ray, electromedical, and picture archiving.

ing know-how in question had originated from within the institution; whether a license had been negotiated between the institution or its agent and the commercializing firm; and if and when the institution had established a formal in-house patent and license office. This stage involved about 60 phone and personal interviews.

Formal in-house patent and license offices varied widely in size and structure. Stafling ranged from one person to about a dozen. Some offices received only five to ten disclosures a year; others received hundreds. Some employed in-house patent attorneys, while others hired off-site attorneys to prosecute patents. License portfolios, too, ranged from very few to several hundred. The defining characteristics of a formal on-campus patent and license office for this study, though, were that the academic institution had an on-campus system for receiving and evaluating disclosures of potentially patentable work from its researchers, and was prepared to file for patents and attempt to license products and process that it thought had commercial potential.

License terms varied widely regarding exclusivity of product and geographic use, pre-commercialization licensing fees and post-commercialization royalty terms, responsibility to obtain patents, responsibility to pursue patent infringement cases, sublicensing rights, rights to follow-up research, application of the agreement to subsequent products, and reversion clauses. In addition, distribution of license revenue across university, department, and researcher varied widely. For this study, the common denominator was that the academic institution or its agent had negotiated an agreement with the manufacturer specifying the terms by which rights to the product would be trans- ferred from the institution to the manufacturer. This criterion excluded cases in which manufacturers reached an agreement with an individual researcher rather than with the institution within the research took place.

Determining whether a license existed was not always a clear cut decision. In few cases, a license was not negotiated before commercialization, but was obtained after the fact; I recorded such instances as cases of license. ${ }^{2}$ Because many of the institutions did not establish formal offices until long after the cases of diagnostic imaging technology transfer had occurred, some of the people

2 Although after-the-fact licensing is relatively common in industrial settings, when commercial firms sue or negotiate to protect patent rights, such licenses traditionally have been rare when an academic institution is the patent holder. In part, universities that were not able to negotiate licenses at the time of transfer have not been any better suited to negotiating licenses later. In addition, many universities have hesitated to seek legal recourse following possible infringements, believing that the possible harm of publicity generated by such actions would outweigh any financial gains, because it might appear that the university was inhibiting technology transfer, rather than assisting it. In this study, the only such cases occurred when after-fact-licenses were negotiated as sublicenses to academic licenses held by commercial firms, although at least one university-based patent and license agency had initiated legal action at the time of the study. A successful model for after-the-fact licensing may be developed in Britain, however, where the British Technology Group recently was formed to act on behalf of several universities throughout the United Kingdom, seeking licenses on diagnostic imaging and other technology for which the universities and the British government hold patents. The Group has successfully negotiated licenses with several European, American, and Japanese firms which have commercialized products that directly or indirectly draw on work carried out at the British institutions. 
could not be certain that a license had or had not been negotiated. Even in those instances, however, they usually were able to judge whether or not a license had been likely. In such a case of weak licensing confirmation, I used the person's judgement as the basis for my record, but also noted that the record was an estimate. In the statistical analysis, I then checked for bias created by including the estimates; no bias emerged. After the interviews with academic licensing personnel, 191 cases of diagnostic imaging technology transfer from 46 institutions remained in the study, with 64 of the cases having been transferred via license between the academic research institution and the commercial manufacturer. The 191 cases are summarized by imaging subfield and decade in Table 1.

Rather than being evenly distributed across all 46 institutions, the transfer and licensing cases are disproportionately represented by two subsets of universities. Several universities with active di- agnostic imaging research programs are most important for the transfer cases. Institutions with active technology licensing offices, meanwhile, dominate the licensing cases. There is not a oneto-one correspondence, however, between imaging research programs and technology licensing offices. Many critical imaging advances have emerged from academic institutions which did not have formal in-house patent and license offices.

\section{Diagnostic imaging equipment technology trans- fer methods}

Classification of technology transfer methods took place in two steps. Transfers were first divided into first and second generation transfers. First generation transfers were those that occurred directly from the academic lab to the commercializing firm. Second generation transfers, meanwhile, involved corporate acquisition of know-how from

Table 2

Transfer methods used to commercialize diagnostic imaging device research conducted at American academic institutions, 1954-1988

\begin{tabular}{|c|c|c|c|c|}
\hline \multirow[t]{2}{*}{ Transfer method } & \multicolumn{3}{|l|}{ License } & \multirow[t]{2}{*}{ Total } \\
\hline & $\begin{array}{l}\text { Academic } \\
\text { license }\end{array}$ & $\begin{array}{l}\text { No academic } \\
\text { license }\end{array}$ & Unknown & \\
\hline \multicolumn{5}{|l|}{ First generation transfer } \\
\hline Hands off: Read literature ${ }^{b}$ & & 10 & & 10 \\
\hline \multicolumn{5}{|l|}{ Individual contact: } \\
\hline Researcher hired ${ }^{c}$ & 4 & 26 & & 30 \\
\hline Faculty or student startup & 6 & 25 & 2 & 33 \\
\hline \multicolumn{5}{|l|}{ Organizational contact: } \\
\hline Arm's length license & 24 & & & 24 \\
\hline Sponsortel project & 17 & 12 & 2 & 31 \\
\hline Academic equity venture & 1 & & & 1 \\
\hline \multirow[t]{2}{*}{ Unknown transfer method } & 1 & $\underline{2}$ & 4 & 7 \\
\hline & 53 & 75 & 8 & 136 \\
\hline \multicolumn{5}{|l|}{ Second generation transfer } \\
\hline \multicolumn{5}{|l|}{ Hands off: Incorporated design ${ }^{c}$} \\
\hline \multicolumn{5}{|l|}{ Individual contact: } \\
\hline New company spawned & & 8 & & 8 \\
\hline \multicolumn{5}{|l|}{ Organizational contact: } \\
\hline Sublicensed from company & 5 & 5 & & 10 \\
\hline \multirow[t]{3}{*}{ Acquired company or interest } & 6 & 31 & & 37 \\
\hline & 11 & 44 & & 55 \\
\hline & $=$ & $\underline{\underline{\underline{u}}}$ & $=$ & $=$ \\
\hline Total & 64 & 119 & 8 & 191 \\
\hline
\end{tabular}


firms that earlier had acquired academic technology. As reported in Table 2, I identified 136 first generation transfers and 55 second generation exchanges.

Within each generation, functional transfer mechanisms were classified as hands off, individual contact, and organizational contact methods. Within the organizational contact method, a markets and hierarchies [29] framework was then chose to further define organizational transfer methods. The classification scheme incorporates Cutler's [7] distinction among publication, people links, and patent transfer methods, but adds information regarding whether people contact took place through individual or organizational means.

Within the first generation, of academic to corporate transfer, the three primary categories were defined in the following manner. The hands off method involved learning about a design by reading the academic literature. ${ }^{3}$ Individual contact included academic researchers being hired by corporations or setting up their own firms. The markets to hierarchies continuum of organizational contact included arms length licenses on the market end, university equity ventures on the hierarchy end, and university-corporate sponsored projects in the middle. Organizational contact, whether by arms length license or sponsored project, frequently also involved individual contact between the corporation and the key researchers.

Most first generation cases involved people links, whether through individual contact or sponsored projects in the organizational category. A significant minority involved arms length licensing within the organizational contact category. Relatively few of the cases identified involved hands off literature review, although this may be an underestimate owing to reluctance to admit having done so.

Within the second generation, of transfer from one corporation to another, the three general categories took on similar meanings to the first generation definitions. The hands off method involved incorporating elements of another company's de-

3 In addition to reading academic literature, other hands off methods of know-how acquisition include attending conferences and visiting laboratories. These were excluded from the study because of the difficulty of obtaining consistent data. sign. The individual contact method involved hiring personnel from another company, which might occur when an established firm hired someone from another established company or when a new firm was set up by an ex-employee of an established company. The organizational contact category included sublicensing at the markets end and acquisition of a firm or part of a firm at the hierarchies end. By far the most common method of second generation transfer identified was acquisition of another company or division or acquisition of an interest in another company. Some cases of sublicensing and of new companies being established by employees of existing firms also occurred.

As noted on Table 2, three categories of technology transfer are excluded. Within the first generation, the table excludes cases of students being hired by a corporate manufacturer, owing to documentation difficulty. Within the second generation, hands off incorporation of one company's design into another firm's product and transfer through ex-employees also are excluded, owing to the reluctance of many corporate personnel to admit having used another company's ideas.

The relative frequency of transfer method has been changing, with changes in the first generation methods being of particular interest in this study. Table 3 reports product-moment correlations of the transfer methods with the year of transfer. The hands off and individual contact methods are declining in relative incidence, while the organizational contact methods of arms length licenses and sponsored projects are increasing. There is no significant change in the relative incidence of researcher startups. The decline in hiring researchers must be interpreted carefully, however, because many of the cases of organizational contact also involve contact with individual researchers.

Table 3

Correlation between first generation transfer method and year, 1954-1988 $(N-135)^{\text {a }}$

\begin{tabular}{|c|c|c|c|c|c|}
\hline \multirow{2}{*}{$\begin{array}{l}\text { Hands } \\
\text { off }\end{array}$} & \multicolumn{2}{|c|}{ Individual contact } & \multicolumn{2}{|c|}{ Organizational contact } & \multirow[t]{2}{*}{ Unknown } \\
\hline & $\begin{array}{l}\text { Hire } \\
\text { researcher }\end{array}$ & $\begin{array}{l}\text { Startup } \\
\text { firm }\end{array}$ & $\begin{array}{l}\text { Arns } \\
\text { length } \\
\text { license }\end{array}$ & $\begin{array}{l}\text { Sponsored } \\
\text { project }\end{array}$ & \\
\hline$-0.16^{*}$ & $-0.18 * *$ & -0.05 & $0.15^{*}$ & $0.16^{*}$ & 0.07 \\
\hline
\end{tabular}


Some transfer methods imply whether a license was negotiated with the institution within which research was conducted. By definition, hands off literature acquisition does not require a license; organizational arms length and equity venture contacts, meanwhile, do require licenses. Other methods, however, may or may not involve an organizational academic license. The next section examines differenees in licensing incidence among the different methods and over time.

\section{Diagnostic imaging equipment academic licens- ing incidence}

As reported in Table 2, whether the transfer took place during the first or second generation of commercialization, licenses were negotiated in only a minority of cases. Of the 128 first generation cases for which I was able to obtain licensing information, only 53 were licensed from the institution. With second generation transfer, licenses with the originating academic institution were even more uncommon; only 11 of 55 recorded cases of second generation transfer an academic license.

However, incidence varied among the different categories. Within the first generation, commercial products that emerged from academic research projects at least partly sponsored by a manufacturer tended to involve formal licenses specifying post-commercialization payment to the institution; a significant minority, however, did not. Licenses were relatively unusual in cases of transfer via researcher employment. In the cases of researcher's students being hired, which 1 omitted from the report owing to incomplete data, licenses also were unusual. And startup firms established by researchers or their students usually did not license the technology from the research institution.

Within the second generation categories, only in sublicensing cases was it common to find the academic institution included in the negotiated terms, but even in this class only half the cases resulted in an academic license, always in cases where the first generation transfer took place via a license specifying that sublicenses must include participation by the university. Few academic licenses were negotiated when one company acquired another. Similarly, when employees of a firm left it to start a new company, licenses were
Table 4

Logistic regression of academic license incidence, 1954-1988 (180 transfers; 63 licenses) $^{a}$

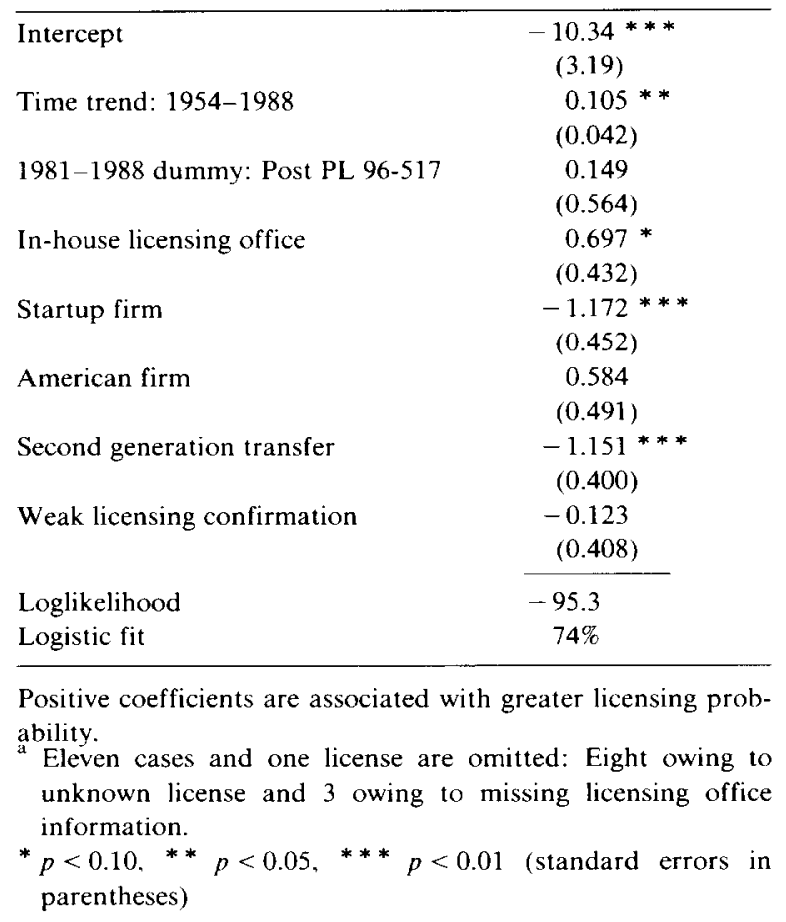

not negotiated back to the originating academic institution. And in the cases of the ornitted second generation class that I did identify, where one firm copied another manufacturer's design or incorporated elements of the design into its own product, academic licenses were not obtained.

Although licensing is low, it has changed over time. Moreover, the incidence has varied depending on whether the originating research institution has a formal patent and license office. Table 4 reports the results of logistic regression analysis used to investigate factors associated with license incidence.

Overall, the specified logistic regression equation provided reasonable explanation of licensing incidence, as shown by the 74 percent fit of predicted to actual cases. I found an increasing trend in licensing incidence during the 1954-1988 period of the study; the later the transfer took place, the more likely a license was negotiated. To capture the effect of Public Law 96-517 of 1980, a second time variable was specified for the 1981-1988 period. The coefficient on this variable was posi- 
tive, but its lack of statistical significance indicates that passage of the law alone did not lead to increased licensing incidence.

However, whether an institution had established a formal patent and license office when the technology transfer took place was associated with positive licensing probability, at moderate statistical significance. Many universities established formal offices only after passage of PL 96-517 had increased their incentive to do so. Indirectly, then, PL 96-517 does appear to have lead to greater licensing incidence, but only at institutions that responded to the incentive and established inhouse patent and licensing operations. Because many of the universities were still in the process of establishing formal offices by the $1980 \mathrm{~s}$, and were still developing licensing policies and routines, the full effects of the law were not felt during the decade of the 1980s. It is likely, therefore, that the incidence of licensing will increase further, as more universities respond to the legal and other incentives by establishing in-house offices, and so gain experience with formal technology transfer.

Because licensing incidence did not increase during the 1980s at institutions that did not establish on-site licensing offices, an implication of this finding is that external agents have been no more successful at obtaining licenses for academic diagnostic imaging technology since the passage of PL 96-517 than they were before the law was passed. For at least three reasons, one must be careful in interpreting this result. First, although the imaging advances have emerged from many universities, major research institutions such as Stanford University, the University of California, and the University of Wisconsin have above-average representation. The major research institutions also tend to possess established in-house licensing operations. Thus, external agents do not represent many sites at which commercializable research is likely to occur. Second, if universities had not set up in-house patent and license operations following the passage of PL 96-517, it is possible that the external agents would have negotiated the licenses that were undertaken by the in-house staff. Third, care must be taken in extending the implication beyond the imaging field. Research Corporation, a key agent for many universities, had traditionally focuses on pharmaceutical agents rather than medical devices. Moreover, with the recent formation of Research Corporation Technologies, Inc., the organization may be expanding beyond its traditional base.

Two secondary results also are interesting. First, American firms were no more likely than their foreign competitors to license technology that they obtained from academic institutions. Second, startup firms were much less likely than established manufacturers to license academic technology. It is possible that startup firms tend to commercialize technology that is not patentable, due to prior publication or general knowledge. However, while it is difficult to determine the potential patentability of cases for which applications were not filed, many licensing personnel believe that much of the technology commercialized by startup firms could have been patented and licensed, had there been a patent office to pursue patent applications and negotiate terms. Certainly, the number of patents applied for and granted has risen, as in-houses offices have been established. In additional, several universities have had a formal or informal understandings that individual researchers who wished to commercialize technology themselves could do so without giving the university patent rights and negotiating a license. At institutions with in-house patent offices, relatively few researchers have followed this option; at institutions without in-house offices, more have done so.

In addition, two control variable provide confidence in the findings. Because most second generation transfers do not involve academic licenses, including such cases in the logistic regression analysis may bias the findings. Therefore, a variable identifying such cases also was included. The strongly negative association confirmed the low licensing probability; at the same time, it did not swamp the earlier coefficients. (A model from which second generation transfers were omitted produced equivalent results.) Also, analysis of the cases in which only estimated licensing information was available disclosed no bias.

\section{Discussion}

This paper has documented methods by which diagnostic imaging device know-how has been transferred from academic institutions to corporate manufacturers and the incidence of licensing during or after the transfer. Many methods have 
been used, but most involve people links, whether solely with a key researcher or in combination with organizational contact. Traditionally, relatively few licenses have been negotiated between the corporations and the academic institutions.

However, the methods chosen and the incidence of licensing are changing. Corporations now are more likely to undertake transfer via sponsored projects than they were during the 1950 s and $1960 \mathrm{~s}$. At the same time, the incidence of licensing is increasing, especially with universities that have established formal patent and license offices.

Although these results apply specifically to the transfer and commercialization of medical diagnostic imaging equipment, they are broadly representative of academic research throughout the medical sector; recent licensing incidence in biotechnology product commercialization, for instance, also is high. Other product sectors, such as computer software and hazardous waste management, also are seeing increases in licensing incidence.

The results of this study, therefore, illustrate the closer organizational contact that is now developing between academic research and corporate commercialization. As markets become more competitive and technology more complex, many facturers are finding that they need to work more closely with basic researchers. At the same time, those universities that have established formal patent and licensing offices are able to negotiate licenses for the transfer of knowledge to the corporations.

Several issues, however, are less clear. Has the incidence of technology transfer increased? Will academic institutions make money from their technology licensing operations? And how can academic technology licensing operations increase the effectiveness of their technology transfer operations? The discussion in the following section is tentative. Nonetheless, I believe that it is pertinent and raises important issues for further study.

\subsection{Has the incidence of technology transfer in- creased?}

Although products that are transferred now are more likely to be licensed, another important issue is whether products are more likely to be transferred. If technology transfer offices simply cap- ture part of the rent stream of products that would have been commercialized anyway, diverting it into pockets of the institutions and the researchers, they are doing part of their job. But it may be the smallest part. Indeed, in a closed economy with a well-functioning tax system and the political will to fund academic research, the rent capture part of the academic technology transfer job would not be necessary. A closed economy, or at least a balance in international technology acquisition, would ensure that the jobs and income resulting from commercialization of academic research accrue to the same economic entity that funded the research. A well-functioning tax system would ensure that the income resulting from the commercialization would return to the political system. And the political will to fun academic research would ensure that the income is recycled into the institutions. (A nirvana in which all three conditions are met, however, seems unlikely.) Of greater import is whether technology patent and license offices increase the likelihood that useful ideas and goods become used.

The folk-lore of academic research contains many stories of potentially useful products that have not been developed. A product may languish in the lab for many reasons [12]. Once the first joy of experimentation has worn off, the researcher may not be interested in the tedious refinement that is necessary for a commercial product. Academics may fail to recognize the commercial potential. Necessary complementary products may not be available. No company may be willing to invest the funds necessary for refinement. Or a match between the product and a suitable company may never be found.

On-site technology patent and license offices cannot solve all these problems. But they do have the potential to solve some of them. They an increase information flow out of the institution, so that potential commercializers are more likely to learn of the product. By ensuring that patent rights are obtained, they can increase the likelihood that some company will invest in further refinement. By acting as a liaison between the researcher and the manufacturer, they can increase the likelihood that a researcher will spend time working on refining the product.

These potential advantages should not be exaggerated. Established manufacturers usually know which researchers are doing research related to 
their products. They often follow their projects closely, sometimes partly funding them, sometimes hiring the researcher on consulting contracts, sometimes hiring his or her students. Patents often will not be an issue, because the firm can protect the value of the new product through its control of supporting products and systems [10]. Because the information and patent protection issues are relatively unimportant in such cases, an academic patent and license office usually will not increase the incidence of such transfers, although it may garner part of the rent stream. And at the other end of the manufacturer spectrum, an entrepreneurial researcher who is determined to set up his or her own commercial shop will not be more likely to do so because a technology transfer office exists.

Nonetheless, significant opportunities to increase the incidence of technology transfer do lie within at least two broad categories. First, a patent and license operation may be able to link an established company with a new product that is out of its existing markets, and so may not be seen by the firm, but which ties in well with an existing capability. An example would be introducing a biotechnology idea to a brewing company, because the brewing process is similar to the process required to produce biochemicals. Second, a patent and license office may be able to help a startup venture get established, through financial, organizational, or informational assistance.

Thus, there are opportunities for technology transfer offices to increase the incidence of technology transfer as well as the incidence of licensing. But the opportunities usually lie outside the realm of bringing incrementally improved existing products to established manufacturers. The opportunities lie in finding major new goods, or bringing new uses for existing goods to new manufacturers.

Has the formation of on-site patent and license offices increased the incidence of diagnostic imaging instrument transfer? The honest answer is fuzzy - probably, but not very much yet, and it needs more study. Many of the transfers have been to established firms and most of those transfers would have occurred anyway. Some transfers, though, involve foreign firms with relatively minor presence in the U.S. It is possible that such firms would not have learned of the research, or would have lacked familiarity with American practices needed to acquire the know-how, if the academic licensing offices did not exist. ${ }^{4}$ And a few cases involve startup firms that received significant organizational assistance from the licensing offices. It is unlikely that those manufacturers would now exist if the academic licensing offices did not operate.

\subsection{Do academic patent and licensing offices make money?}

If one goal for an academic patent and license office is to raise money for the institution and the researchers within it, how well is that goal being achieved? If the measure is licensing income, most offices do not make very much. Although offices vary widely in how they calculate income and expenses, very few report annual income in excess of two million dollars. ${ }^{5}$ Given current research support demands, even at a small university, this is not much money. Although licensing revenues will rise as licensing offices become more experienced, the income will rarely support more than a small proportion of academic research. Most license agreements do little more than cover their costs; and the elusive big hit is satisfying when it arrives, but will rarely be a line item in a university budget.

4 A fear frequently expressed in Washington and in the popular press is that foreign firms may obtain knowledge from American universities and transfer it abroad. This certainly occurs. On the other hand, American firms also benefit from research undertaken in foreign universities, and it is not clear that the American technological trade balance is strongly negative. Therefore, few license agreements between United States academic institutions and foreign firms represent an attack on American industrial competitiveness. Moreover, a foreign firm obtaining technology from a U.S. institution frequently establishes research and manufacturing operations in the United States, close to the institution, in order to realize the tacit benefits of ongoing research contact. Thus, technology transfer from American universities to foreign manufacturers often results in American economic development.

5 With its focus on the commercialization of diagnostic imaging technology, this was not an inclusive study of all American academic institutions. The institutions surveyed, however, included most major American academic research sites. Of the 35 institutions which provided estimates of gross revenue, 11 reported annual technology transfer income in excess of $\$ 1$ million. The range was from nothing to almost $\$ 10$ million, with a mean of $\$ 1.2$ million. 
It is not clear, though, that licensing revenue is the appropriate measure of financial success. A more useful measure would include all income that would not have been received by the university if the licensing office did not exist. Besides licensing fees and royalties, such income may include sponsored projects that require clear patent title, and federal research grants that require commercial technology transfer follow-up. In addition, if a patent and license office satisfies faculty demands for maintenance of a commercial conduit for their research, a university may find it easier to attract and retain high-profile researchers. Those researchers may, in turn, attract public and corporate research support.

Measuring such income accurately is difficult. Including all sponsored project and public research support income would greatly overstate the impact of a licensing office. But omitting all nonlicensing income will understate the impact and perhaps reduce support for the licensing office. Therefore, the topic remains a fruitful area for further study.

\subsection{How can licensing offices transfer technology effectively?}

Occasionally, technology licensing requires only three simple steps: file for a patent on a commercializable product, negotiate a license with an available firm or firms, and then sit back to receive royalties. But such cases are rare. Instead, each of the three steps is usually highly uncertain.

The commercial of a newly disclosed product is usually unclear. Because prosecuting a patent is relatively expensive, a licensing office cannot file for patent protection on every item that is disclosed to it. Thus, it must make commercial judgements. In addition, it must decide whether to file only in the U.S. or to incur the additional expense of obtaining foreign patent protection. It must also find licenses. Sometimes, an appropriate licensee is obvious, perhaps because the researcher responsible for the patented product has already identified a manufacturer for it. More often, though, candidates for licensing are much harder to find. Licensing offices must publicize their holdings and licensing personnel must establish networks of trade contacts. And even after a licensee has been identified and agreement has been reached, some monitoring is often necessary to be sure that the terms of the agreement are met. Thus, carrying out the basic tasks of prosecuting patents and negotiating licenses requires experience and judgement.

In-house academic patent offices have been much more likely that external agents to file for patents on disclosed products. Partly because of pressure from local researchers, partly because of their greater familiarity with local opportunities, they have been more willing to take on the expense of building patent portfolios. By creating patent portfolios, they have begun to accomplish each of their two main jobs - obtaining revenue if a product is successful and increasing the chance of technology transfer by ensuring that patent protection is secure.

But building a patent portfolio does not alone generate effective technology transfer. Relatively little transfer takes place through arms length agreements. Referring back to Table 2, we see that such agreements are a minority of diagnostic imaging device licenses. Because research designs are usually far from commercially ready, much additional work and money must be expended to bring them to market. And because the additional work often must draw on tacit knowledge held by the developer, ongoing contact between the research site and manufacturing personnel is usually necessary. Even the diagnostic imaging devices cases classified as arms length agreements of ten involved post-license contact between the researcher and the manufacturer. Thus, the patent and license office must be able to negotiate the terms of such research development contact.

If the licensee is a startup venture or a small firm, rather than an established manufacturer, the task of the licensing office becomes even more difficult. Rather than simply receive a share of the firm's revenue, in the form of royalty cheques, the licensing office must often help the venture become organized enough to generate income in the first place. Hence, licensing personnel, like commercial loans officers in a financial institution, sometimes must also be part-time managers of their clients.

The task of dealing with a small firm becomes particularly acute when the university has an equity position in it. Many universities are now experimenting with taking equity positions in startup ventures, hoping both to garner revenue from products that traditionally have left the uni- 
versity without a license (recall, from Table 4 , that startup ventures were much less likely that cstablished firms to negotiate licenses) and to increase the incidence of technology transfer [12]. Although only one equity venture shows up in the diagnostic imaging device data in Table 2 (two other cases were still at the research prototype stage and were omitted from the study), there are several hundred such projects now under way.

The terms under which equity participation ventures are established vary widely. In some cases, the equity is held directly by the university; in others, the university has established a for-profit subsidiary to invest in the ventures. Usually, the university's equity position is received in lieu of royalties and/or license fees, but in some cases the university or a subsidiary established by it also has invested cash in the new venture. Sometimes academic licensing personnel take an active role in advising management, but often they step back, at least once the venture is underway. Often the university or its subsidiary take an active part in finding venture capital for the new firm. Because almost all such equity ventures have emerged within the past five years, it is too early to identify the most successful models. In general, however, taking an equity position in a new venture will entail all the difficulties of dealing with a small firm, plus potential financial, organizational, legal, and political issues related to the university's dual status as research institution and commercial shareholder.

To summarize this section, effective technology transfer can be broken into two parts. One part includes the basic tasks of an academic patent and license office. By obtaining appropriate patents on products with commercial potential, the office lays the ground work for garnering revenue from licenses and other revenue sources. It may also increase the incidence of technology transfer, by ensuring that patent protection exists, thus providing incentives for firms to invest in additional development. But technology transfer does not consist solely of patenting and licensing.

A far bigger part of technology transfer consists of research development work [19]. Such research development has at least three components. One is information dissemination - linking commercializable products with capable manufacturers. A second is managing flows of tacit information - assisting research and manufacturing personnel to maintain the long-term contact that is usually needed to bring a research prototype to commercial production. And a third component of research development that is sometimes necessary is providing organizational support for the commercializing firm.

The research development part of the work of the patent and license office is likely to intersect with other operations throughout the university sponsored project offices, research and industrial parks, university attorneys, and industry liaison offices, for example. The institutional form of the intersections varies by university. In some, whether for size or historical reasons several of the operations are housed in one office. In many, though, operations that may influence the effectiveness of technology transfer are spread throughout the campus or across a multi-campus system. Thus an academic patent and license office must not only coordinate its contact with external licensees, it must coordinate its work with internal development agencies. Compounding the coordination chore, the work may also intersect with national research development organizations, such as the National Technical Information Service or the British Technology Group. Effective technology transfer is much like effective business operation - it requires both technical and organizational skills.

\section{Conclusion}

Universities are important sources of industrial advances. Some results are spectacular, such as gene-splicing and magnetic resonance imaging. Others are incremental improvements, such as coils for a magnetic resonance system. But whether spectacular or seemingly mundane, the advances effect the way we live and work.

Commercial products developed from academic research prototype have sometimes produced income for the institutions within which the research was carried out. Stanford University and the University of California, for example, have received millions of dollars of royalty income from the Cohen-Boyer recombinant DNA patents. More frequently, though, the potential revenue has not been realized. Most technology transfer has occurred informally, via consulting, students, publications, conferences, and other venues. 
Although contact between individual researchers and commercializers continues to be critically important, organization level contact between American academic institutions and corporate manufacturers is becoming more common. Most revenue-generating agreements have occurred on campuses that operate on-campus patent and license offices, rather than depend solely on off-campus agents. In the last decade, many research institutions have set up such offices, hoping to tap into the revenue stream that flows from their research. At the same time, the institutions hope to increase the incidence of technology transfer, by providing conduits between their researchers and commercial manufacturers. The explosion of new in-house operations is still too recent to be judged. So far, no operation has been wildly successful. But most appear to be at least paying their way.

Many of the on-campus patent and license operations are experimenting with new research development models, especially forms of equity participation. At the same time, the licensing offices are learning how to coordinate their research development work with other on-campus and external agencies. Watching and influencing the development of these models of licensing and research development will be fascinating and important activities for many years to come.

\section{References}

[1] S.D. Atchison, Meet the Campus Capitalists of Bionic Valley, Business Week 2945 (May 1986) 114-115.

[2] D.R. Baldwin, Technology Transfer at The University of Washington, Journal of the Society of Research Administrators 17 (4) (Spring 1986) 13-26.

[3] H.W. Brcmer, Research Applications and Technology Transfer, Journal of the Society of Research Administrators 17 (2) (Fall 1985) 53-65.

[4] W.S. Brown, A Proposed Mechanism for Commercializing University Technology in: J.A. Hornaday et al. (eds), Frontiers of Entrepreneurship Research (Babson College, Wellesly, MA, 1984) 395-401.

[5] H.B. Chermside, Some Ethical Conflicts Affecting University Patent Administration (Part 1), Journal of the Society of Research Administrators 16 (3) (Winter 1985) 23-34.

[6] J.H. Comroe, Jr. and R.D. Dripps, The Top Ten Clinical Advances in Cardiovascular-Pulmonary Medicine and Surgery: 1945-1975, DHEW Publication Number (NIH) 78-1521 (Department of Health, Education and Welfare, Washington, D.C., 1977).
[7] R.S. Cutler, A Comparison of Japanese and U.S. HighTechnology Transfer Practices, IEEE Transactions on Engineering Management 36 (1) (February 1989) 17-24.

[8] D.R. Fowler, University-Industry Research Relationships, Research Management (January-February 1984) $35-41$.

[9] K.W. Heathington, B.S. Heathington and A.J. Roberson, Commercializing Intellectual Properties at Major Research Universities: Income Distribution, Journal of the Society of Research Administrators 17 (4) (Spring 1986) 27-38.

[10] R. Levin, A. Klevorick, R. Nelson, and S. Winter, Appropriating the Returns from Industrial Research and Development, Papers on Economic Activity 3 (1987).

[11] J. Main, Business Goes to College for a Brain Gain, Fortune 115 (6) (March 1987) 80-89

[12] W.E. McMullan and K. Melnyk, University Innovation Centres and Academic Venture Formation, $R \& D$ Management 18 (1) (1988) 5-12.

[13] I. Meschan and D.J. Ott, Introduction to Diagnostic Imaging (W.B. Saunders Company, Philadelphia, 1984).

[14] W. Mitchell, Medical Equipment Technical Development and Commercialization: A Parallel Model (University of Michigan, School of Business Administration, Working Paper, March 1990).

[15] S. Meyers and D.G. Marquis, Successful Industrial Innovation, Report No. 69-17 (National Science Foundation, Washington, D.C., 1969).

[16] National Science Foundation, University-Industry Research Relationships: Myths, Realities, and Potentials. Fourteenth Annual Report of the National Science Board (Government Printing Office, Washington, D.C.. 1982).

[17] K. Pavitt and S. Wald, Conditions for Success in Technological Innovation (OECD, Paris, 1971).

[18] B.D. Reams, Jr. University-Industry Research Partnership: The Major Legal Issues in Research and Development Agreements (Quorum Books, Westport, CT, 1986).

[19] N. Reimers, Directed Mechanisms for Innovation, reprinted in: Robert Goldscheider and Tom Arnold (eds), The Law and Business of Licensing: Licensing in the 1980s (Clark Boardman Company, Ltd.. Les Nouvelles, 15 (2). New York, NY, 1986) 3G: 3-30.

[20] R. Stankiewicz, Academics and Entrepreneurs: Developing University-Industry Relations (St. Martin's Press Inc., New York, NY, 1986).

[21] U.S. Congress, Office of Technology Assessment, Policy Implications of the Computed Tomography (CT) Scanner (Government Printing Office, Washington, D.C., 1978).

[22] U.S. Congress, Office of Technology Assessment, Policy Implications of the Computed Tomographic (CT) Scanner: An Update (Government Printing Office, Washington, D.C., 1981).

[23] U.S. Congress, Office of Technology Assessment, Federal Policies and the Medical Devices Industry, OTA-H-230 (Government Printing Office, Washington, D.C., 1984a).

[24] U.S. Congress, Office of Technology Assessment, Health Technology Case Study 27: Nuclear Magnetic Resonance Imaging Technology $\wedge$ Clinical, Industrial and Policy Analysis, OTA-HCS-27 (Government Printing Office, Washington, D.C., 1984b).

[25] E. von Hippel, A Customer-Active Paradigm For In- 
dustrial Product Idea Generation, Research Policy 7 (1976) 212-239.

[26] E. von Hippel, Sources of Innovation (Oxford University Press, New York, NY, 1988).

[27] M. Waissbluth, G. Cadena and J.L. Solleriro, Linking University and Industry: An Organizational Experience in Mexico, Research Policy 17 (1988) 341-347.
[28] C. Weiner, Universities, Professors, and Patents: A Continuing Controversy, Technology Review 89 (2) (February-March 1986) 32-43.

[29] O. Williamson, Markets and Hierarchies: Analysis and Antitust Implications (Free Press, New York, NY, 1975) 